\title{
Spawning pattern of the neon flying squid Ommastrephes bartramii (Cephalopoda: Oegopsida) around the Hawaiian Islands
}

\author{
Dharmamony Vijai ${ }^{1}$, Mitsuo Sakai ${ }^{2}$, Yoshihiko Kamei ${ }^{1}$, Yasunori Sakurai ${ }^{1}$ \\ ${ }^{1}$ School of Fisheries Sciences, Hokkaido University, 3-1-1 Minato-cho, Hakodate, Hokkaido 041-8611, Japan. \\ E-mail: vijai@ec.hokudai.ac.jp \\ ${ }^{2}$ Tohoku National Fisheries Research Institute, 25-259 Shimo-mekurakubo, Samemachi, Hachinohe, \\ Aomori 031-0841, Japan.
}

\begin{abstract}
Summary: The neon flying squid, Ommastrephes bartramii, is an oceanic squid species that is widely distributed in the North Pacific, with the winter-spring cohort spawning around the Hawaiian Islands. Here, we investigated the spawning characteristics of $O$. bartramii by analyzing various reproductive parameters of individuals ( 622 males, 108 females) collected in this region. Female spawning status was determined from the somatic indices and histological characteristics of the ovaries. At all developmental stages, the ovaries of spawned females contained oocytes, and oviduct fullness was not correlated with body size. Thus, because the eggs mature asynchronously, with multiple filling and evacuation events, this species is considered an intermittent spawner. Mature males with developed accessory glands were also present within the distribution range of healthy spawned females, indicating that mating occurs between spawning events. Our data indicate that the first spawning event occurs at a mantle length of $\sim 520-540 \mathrm{~mm}$ for Hawaiian $O$. bartramii. Subsequently, the squid forage and grow, and refill the oviducts, before the second spawning event occurs.
\end{abstract}

Keywords: North Pacific; squid; Ommastrephes bartramii; reproductive strategy; spawning pattern.

Patrón de desove de la pota saltadora Ommastrephes bartramii (Cephalopoda: Oegopsida) alrededor de las islas de Hawai

Resumen: La pota saltadora, Ommastrephes bartramii, es una especie de calamar oceánico que se encuentra ampliamente distribuido en el Pacífico Norte, con la cohorte de desove de invierno-primavera situada alrededor de las islas Hawai. El presente estudio investiga las características de desove de $O$. bartramii mediante el análisis de diversos parámetros reproductivos de ejemplares (622 machos, 108 hembras) recolectados en esa región. El nivel de desove de las hembras se determinó a partir de índices somáticos y características histológicas de sus ovarios. En todos los estadios de desarrollo, los ovarios de las hembras desovantes contenían oocitos, en tanto que el grado de llenado de los oviductos no se correlacionó con el tamaño del cuerpo. Así, debido a que los oocitos maduran de forma asincrónica, con múltiples eventos de llenado y liberación, se considera a esta especie como desovante intermitente. Se recolectaron machos maduros con glándulas accesorias desarrolladas en el rango de distribución de las hembras desovantes, indicando que las cópulas se producen entre estos eventos de desove. Nuestros datos indican que en $O$. bartramii de la zona de Hawaii el desove inicial se produce a $~ 520-540 \mathrm{~mm}$ de longitud del manto. Posteriormente, el calamar se alimenta y crece, volviendo a rellenar sus oviductos antes de que aparezca el segundo evento de desove.

Palabras clave: Pacífico Norte; calamar; Ommastrephes bartramii; estrategia reproductora; patrón de desove.

Citation/Como citar este artículo: Vijai D., Sakai M., Kamei Y., Sakurai Y. 2014. Spawning pattern of the neon flying squid Ommastrephes bartramii (Cephalopoda: Oegopsida) around the Hawaiian Islands. Sci. Mar. 78(4): 511-519. doi: http://dx.doi.org/10.3989/scimar.04112.27B

Editor: R. Villanueva.

Received: June 16, 2014. Accepted: October 14, 2014. Published: October 27, 2014.

Copyright: () 2014 CSIC. This is an open-access article distributed under the Creative Commons Attribution-Non Commercial Lisence (by-nc) Spain 3.0.

\section{INTRODUCTION}

All living cephalopods are considered semelparous (i.e. characterized by a single reproductive event;
Boyle 1983, Calow 1987, Rodhouse 1998) with the only exception being Nautilus, which has a life span of more than 20 years (Rocha et al. 2001). However, recently, several authors (Nigmatullin et al. 1996, Nig- 
matullin 2002, Nigmatullin 2011) have reported complex reproductive patterns that cannot be categorized as semelparous, particularly in tropical and subtropical oegopsid squids belonging to the family Ommastrephidae. For example, intermittent spawning without somatic growth between spawning events has been reported for Illex coindetii (González and Guerra 1996), Todaropsis eblanae (Rasero et al. 1995) and Illex illecebrosus (O'Dor and Dawe 1998). Furthermore, intermittent spawning with somatic growth between spawning events has been reported for Ommastrephidae (Reznik and Bessmertnaya 1993, Nigmatullin and Laptikhovsky 1994, Nesis 1996, Laptikhovsky and Nigmatullin 2005, Nigmatullin and Markaida 2009). Recently, iteroparity has also been reported in the squid Kondakovia longimana (Laptikhovsky et al. 2013).

The neon flying squid, Ommastrephes bartramii, is an oceanic squid that occurs in subtropical and temperate waters worldwide (Roper et al. 2010). The population in the North Pacific includes an autumn spawning cohort and a winter-spring spawning cohort (Yatsu et al. 1998). Individuals live for one year, migrating between the spawning grounds in tropical waters and foraging grounds in sub-Arctic waters during this period (Bower and Ichii 2005, Chen and Chiu 2003, Murata and Nakamura 1998, Yatsu et al. 1998). The main spawning and nursery ground of the autumn cohort occurs in the subtropical frontal zone (STFZ) of the north Pacific Ocean. This location is characterized by enhanced productivity in winter because of its proximity to the transition zone chlorophyll front (TZCF). In comparison, the spawning and nursery ground of the winter-spring cohort occurs within the subtropical domain (STD), which is less productive (Ichii et al. 2009). The STFZ is defined by a salinity range of 34.6 to 35.2 at the sea surface, generally occurring at $\sim 29$ to $34^{\circ} \mathrm{N}$ latitude, with the STD occurring to the south of the STFZ (Ichii et al. 2009, Roden 1991). O. bartramii are considered to be paralarvae (i.e. young cephalopods in the planktonic stages) from hatching to one month of age (Bigelow and Landgraph 1993), juveniles and subadults from one month of age until they reach a mantle length (ML) of $\sim 25 \mathrm{~cm}$ (Ichii et al. 2009), and adults above $25 \mathrm{~cm}$ ML.

The oocytes develop in the ovary, which extends from the posterior end of the digestive gland to approximately the posterior end of the mantle. Ova are released from the ovary and accumulate in the oviducts. The nidamental glands produce the outer layer of the egg mass (Bower and Sakurai 1996). Females store viable sperm in the buccal area, so mating and spawning do not need to coincide (Harman et al. 1989). Closely related Dosidicus gigas and Sthenoteuthis pteropus ommastrephid females spawn in pelagic waters, producing spherical egg masses (Laptikhovsky and Murzov 1990, Staaf et al. 2008). For two O. bartramii collected from the Atlantic ocean Laptikhovsky (2011) calculated a potential fecundity of 4.9 and 3.7 million eggs. The sperm duct of males transfers the sperm from a testis that is located to the anterior of the spermatophoric organ, where spermatophores are formed. Spermatophores are tubular structures stored in the spermatophoric sac (Needham's sac), which opens into the mantle cavity through the penis (Jereb and Roper 2010). In cephalopods, allometric growth relationships between somatic, reproductive, and digestive components change during ontogeny, depending on the state of maturity and nutritional status (Boyle and Rodhouse 2005). These allometric growth relationships may provide a way of directly determining the spawning status of neon flying squid individuals that are collected from the sea.

In this study, we aimed to examine the reproductive characteristics of the winter-spring cohort of $O$. bartramii near the Hawaiian Islands, using individuals collected from 1990 to 2000 and 2013. The findings of this study, combined with the results of previous studies, are expected to clarify whether this species invests in single or multiple spawning.

\section{MATERIALS AND METHODS}

\section{Sampling}

Squid were collected near Hawaii aboard R/V Hokusei Maru (Hokkaido University, Japan) and R/V Kaiyo Maru (Fisheries Research Agency, Japan). Sampling aboard R/V Hokusei Maru was performed by manual jigging, gillnetting, and trawling on 11 cruises from February to March every year from 1990 to 2000, between the latitudes of 20 and $35^{\circ} \mathrm{N}$ and the longitudes of 150 and $180^{\circ} \mathrm{W}$. Collection aboard R/V Kaiyo Maru was conducted in December 2013 in the sea to the north of Hawaii, between the latitudes of 33 and $24^{\circ} \mathrm{N}$ and the longitudes of 173 and $155^{\circ} \mathrm{W}$. A total of 719 (622 males, 97 females) individuals were collected by R/V Hokusei Maru (from 78 stations), in addition to 11 individuals (all females) by R/V Kaiyo Maru (from 8 stations). All squids were used in the analysis. Monthly data from the 1990-2000 survey years (excluding 2013) were combined because interannual variation in ML is thought to be minimal (Murata and Hayase 1993, Yatsu et al. 1998).

\section{Analysis of the reproductive system}

For the analysis, we selected female squid that had an ML > $400 \mathrm{~mm}$ and male squid that had an ML $>300 \mathrm{~mm}$, to ensure that only mature squid were included in the analysis. Dorsal ML (to the nearest 1 $\mathrm{mm}$ ) was measured, and the following parameters were estimated: body weight (to the nearest $1 \mathrm{~g}$ ), stomach weight, and digestive gland weight (Laptikhovsky and Nigmatullin 1992, 1993). We obtained the testis weight and accessory gland weight of males (Nigmatullin et al. 2003). We also obtained the ovary weight, oviduct weight, nidamental gland length, nidamental gland weight, and mating status (copulated or not) of females. Just 11 of the female squid collected by R/V Kaiyo Maru were used for the analysis of oocyte size and potential fecundity (PF). To determine the number of oocytes in each ovary, we collected three subsamples $(100 \mathrm{mg})$ from the ovary surface, ovary core and intermediate layer. Each subsample was weighed and 
Table 1. - Definitions of somatic indices in Ommastrephes bartramii (BW=body weight in g) (Kidokoro and Sakurai 2008).

\begin{tabular}{llc}
\hline & \multicolumn{1}{c}{ Index } & Definition \\
\hline SCI & Stomach Content Index & Stomach content weight $\times 100 / \mathrm{BW}$ \\
TSI & Testis Somatic Index & Testis weight $\times 100 / \mathrm{BW}$ \\
OSI & Ovary Somatic index & Ovary weight $\times 100 / \mathrm{BW}$ \\
ODSI & Oviduct Somatic Index & Oviduct weight $\times 100 / \mathrm{BW}$ \\
AGSI & Accessory Gland Somatic Index & Accessory gland weight $\times 100 / \mathrm{BW}$ \\
NSI & Nidamental Gland Somatic Index & Nidamental gland weight $\times 100 / \mathrm{BW}$ \\
HSI & Hepato Somatic Index & Digestive gland weight $\times 100 / \mathrm{BW}$ \\
\hline
\end{tabular}

then observed in a Bogorov chamber under a binocular microscope (Nigmatullin and Markaida 2009). PF was calculated as the sum of total oocyte $(>0.05 \mathrm{~mm}$ in diameter) number in the ovary and total egg number in the oviducts (Nigmatullin et al. 1995, Nigmatullin 1997, Laptikhovsky and Nigmatullin 1999, Nigmatullin and Laptikhovsky 1999). Oviducal load (OL) is the number of eggs in the oviducts (Nigmatullin and Markaida 2009).

We used the allometric growth relationships of somatic and reproductive components to determine the spawning status of $O$. bartramii directly. Specifically, we calculated and analyzed the somatic indices of female squid and the volume of oocytes in the ovaries to determine spawning status. The somatic indices used in this study were calculated using the definitions shown in Table 1. Reproductive maturity was assessed on the basis of the maturity stages I to VII proposed by Nigmatullin (1989). These stages were adjusted for the neon flying squid, whereby stages I and II were defined as immature, stage III as early maturing, stage IV as late-maturing, stage $\mathrm{V}$ as mature, stage VI as spawning state (after the first spawn), and stage VII as true spent. Stage VII squid were not collected during any of the cruises. Statistical analyses were performed using $\mathrm{R}$ software (R Core Development Team 2013).

\section{RESULTS}

\section{Somatic indices}

The somatic indices of 622 males and 97 females (1990-2000 data) were analyzed. Females (ML: $526 \pm 4.5 \mathrm{~mm}$, mean $\pm \mathrm{SE}$ ) were larger than males (ML: $333 \pm 0.7 \mathrm{~mm}$ ). All females with $\mathrm{ML}>400 \mathrm{~mm}$ had eggs in the oviducts, indicating that all individuals had attained stage IV sexual maturity or above. Another indicator of sexual maturity in females is the relative size of the nidamental glands (Durward et al. 1979, Okutani and Tung 1978). The nidamental glands of mature females were relatively large, opaque, and white. The glands ranged in size from 68 to $190 \mathrm{~mm}$, and represented $0.9 \%$ to $4 \%$ of the total body weight in individuals of $>400 \mathrm{~mm}$ ML. The nidamental gland index differed significantly among maturity stages IV, $\mathrm{V}$, and VI $(\mathrm{P}<0.01$, analysis of variance [ANOVA]; Fig. 1). Nidamental gland weight increased from the late-maturing stage to the mature stage and decreased after spawning (spawning state). Nidamental gland weight was positively correlated $(\mathrm{r}=0.56, \mathrm{P}<0.01)$ with ML. Within each of the three stages (IV, V, and $\mathrm{VI})$, neither $\mathrm{ML}\left(\mathrm{F}_{2,83}=1.8, \mathrm{P}>0.05\right.$, ANOVA) nor body weight $\left(\mathrm{F}_{2,83}=2.9, \mathrm{P}>0.05\right.$, ANOVA $)$ differed

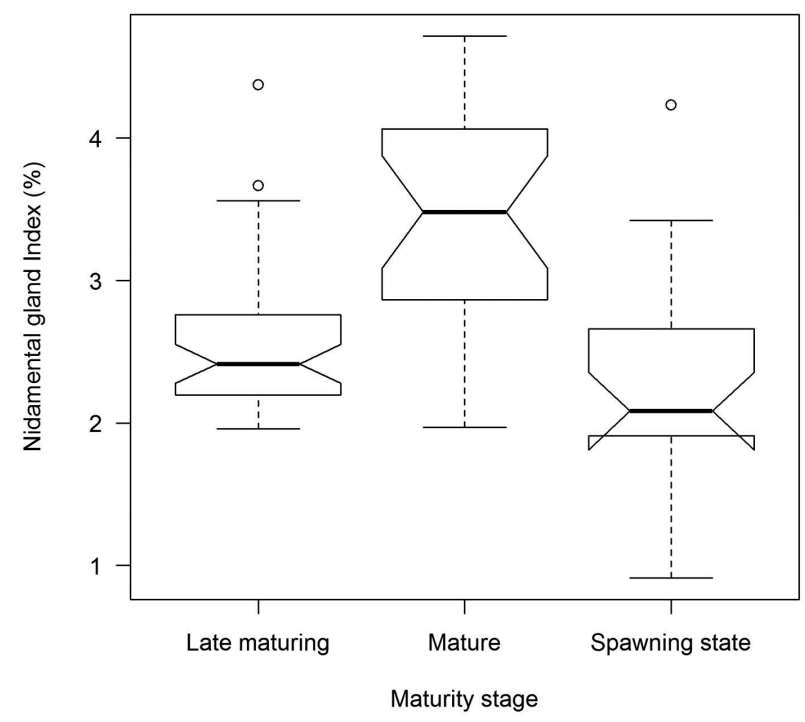

Fig. 1. - Box plots showing variation in nidamental gland somatic index among the three stages of maturity for Ommastrephes bartramii. The median (horizontal black lines within box plots) and its confidence interval (notches) also indicated. There were significant differences among the three stages $(\mathrm{P}<0.01$, analysis of variance).

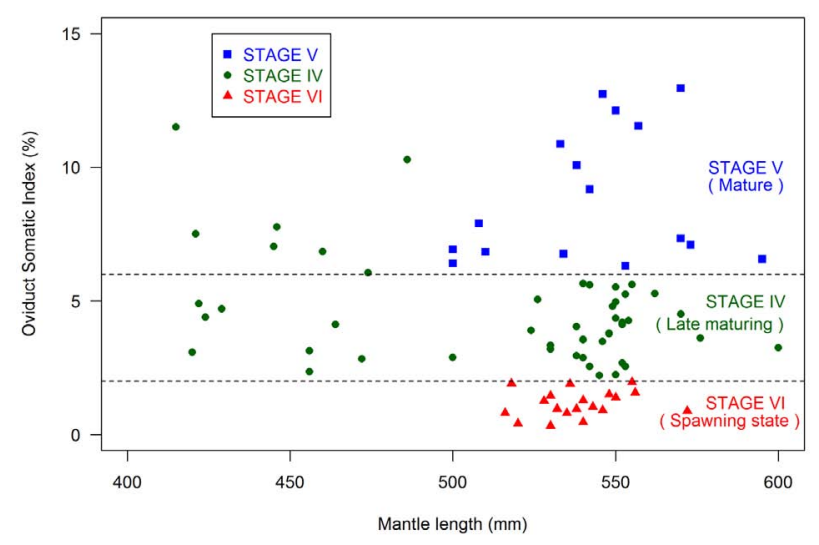

Fig. 2. - Mantle length distribution in relation to the oviduct somatic index and stages of maturity for the female squid Ommastrephes bartramii.

significantly. Stage VI females ranged in size from 516 to $572 \mathrm{~mm}$ ML.

The oviduct index (ODI) distribution of females was scattered (Fig. 2). This index showed no correlation with ML (Spearman rank coefficient $r=0.148$, $\mathrm{P}>0.05)$ in females with $\mathrm{ML}>400 \mathrm{~mm}$. Although there was considerable scatter in ODI among mature individuals, there was no evidence that any female was dying. All mature females had food in the stomach. In addition, the weight of the stomach content in stage VI 


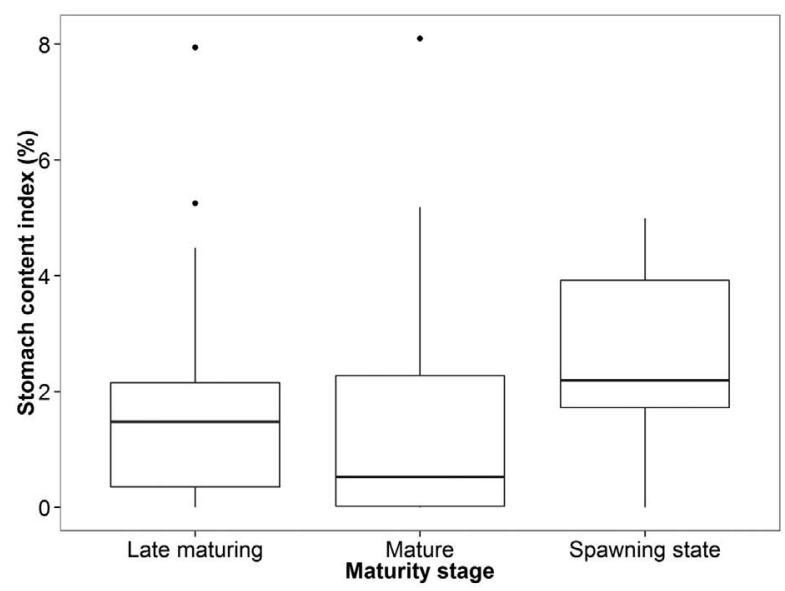

Fig. 3. - Boxplot showing variation in stomach content among the three stages of maturity of Ommastrephes bartramii. There were no significant differences among the three stages $\left(\mathrm{F}_{2,74}=1.85, \mathrm{P}>0.05\right.$, analysis of variance)

females (spawning state) was similar to that of stage IV and $\mathrm{V}$ females $\left(\mathrm{F}_{2,74}=1.85, \mathrm{P}>0.05\right.$, ANOVA; Figs 3 and 4). The ovary index was also not correlated with ML (Spearman rank coefficient $\mathrm{r}=0.031, \mathrm{P}>0.05$ ). Female squid of advanced maturity stages had large ovaries (ovary somatic index [OSI]: 4.34 $\pm 0.83 \%$, Figs 4 and 5, Table 2).

There was a negative correlation between the testis index and ML (Spearman rank coefficient $r=-0.48$, $\mathrm{P}<0.001$ ) of males. However, there was no significant correlation between the accessory gland index and ML (Spearman rank coefficient $\mathrm{r}=-0.04, \mathrm{P}>0.05$ ) of males.

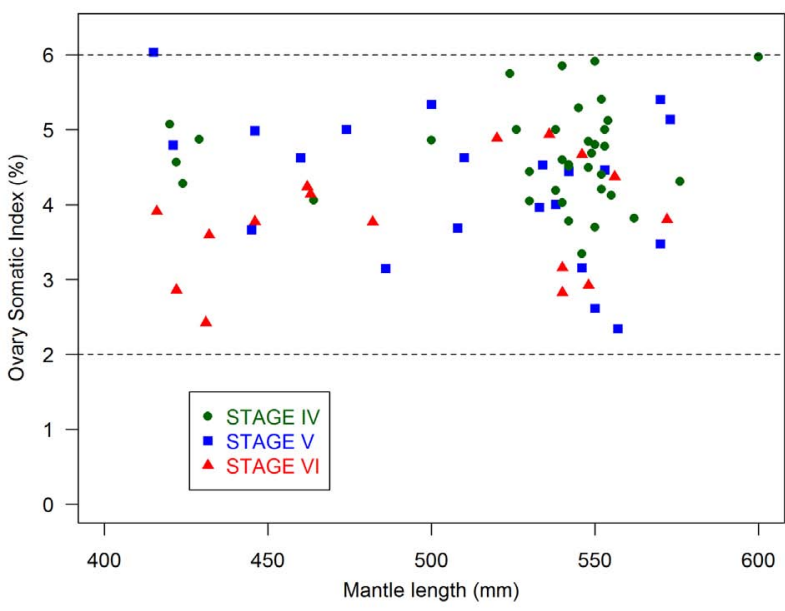

Fig. 5. - Mantle length distribution in relation to the ovary somatic index and maturity stages of Ommastrephes bartramii.

\section{Oocyte size and fecundity}

The oocytes in the ovaries of mature females were at various stages of development, indicating asynchronous development. It was possible to distinguish six size groups of oocytes that corresponded to the stages of oocyte development (after Nigmatullin et al. 1995). Size group I corresponded to the second phase of provitellogenesis, in which oocytes were polygonal and the centrally situated nucleus was oval and large. Group II corresponded to the third phase of provitellogenesis. Oocytes were either oval or goblet-shaped and the cytoplasm volume was greater than that of the

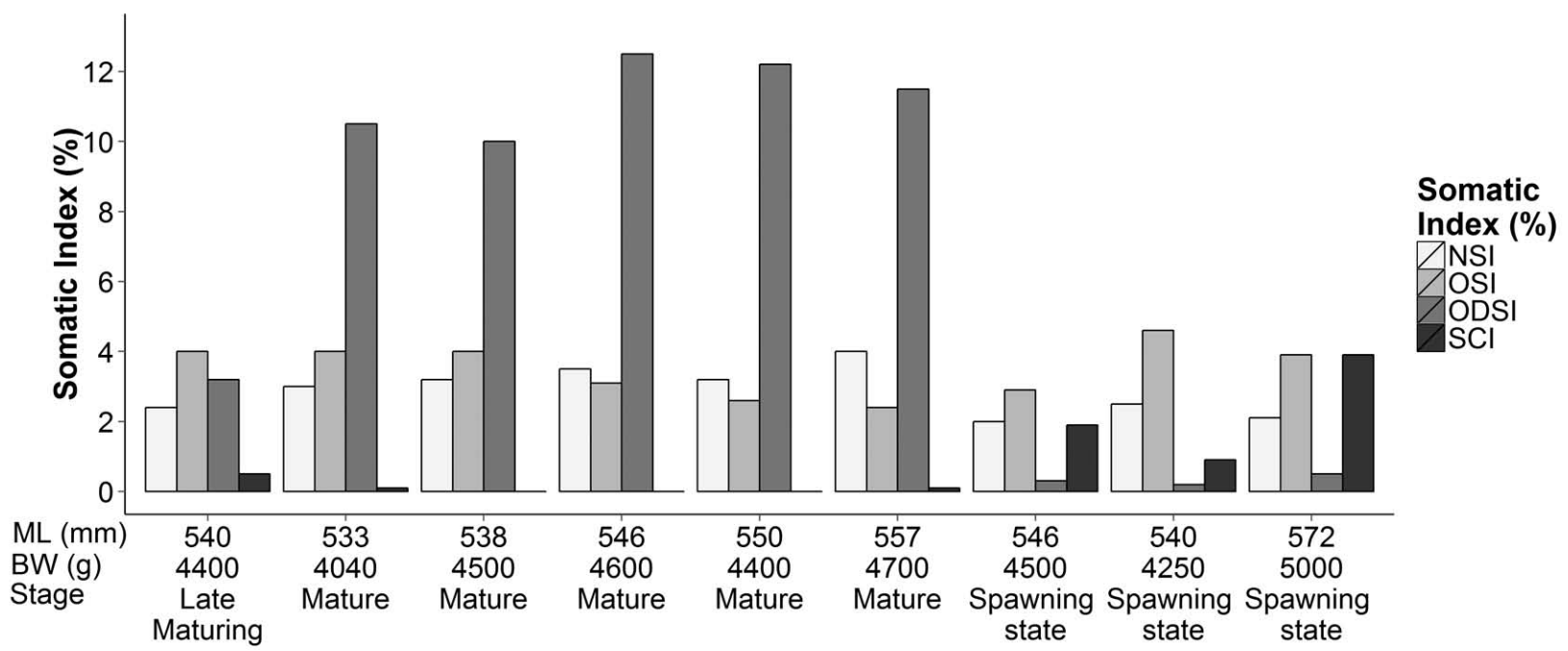

Fig. 4. - Somatic indices of the squid Ommastrephes bartramii at the three stages of maturity (late-maturing, mature, and spawning state) collected in February 1992. BW, body weight; ML, mantle length; NSI, nidamental gland somatic index; ODSI, oviduct somatic index; OSI, ovary somatic index; SCI, stomach content index.

Table 2. - Mean \pm SD and range values for the size (mantle length, ML) and weight (body weight, BW) of female Ommastrephes bartramii. Mean values are shown for the stomach content index (SCI), ovary somatic index (OSI), nidamental gland somatic index (NSI), and Hepato somatic index (HSI).

\begin{tabular}{|c|c|c|c|c|c|c|c|c|c|c|}
\hline \multirow{2}{*}{$\begin{array}{l}\text { Maturity } \\
\text { stage }\end{array}$} & \multicolumn{3}{|c|}{ ML (mm) } & \multicolumn{3}{|c|}{$\mathrm{BW}(\mathrm{g})$} & \multicolumn{4}{|c|}{ Mean indices $(\%)$} \\
\hline & Min. & Mean \pm SD & Max. & Min. & Mean \pm SD & Max. & SCI & OSI & NSI & HSI \\
\hline VI & 416 & $493.6 \pm 53.9$ & 572 & 2165 & $3645.6 \pm 1057.3$ & 5650 & $2.6 \pm 1.49$ & $3.8 \pm 0.76$ & $2.3 \pm 0.78$ & $6.58 \pm 2.05$ \\
\hline $\mathrm{V}$ & 415 & $507 \pm 61.2$ & 595 & 2260 & $4154.6 \pm 1034.7$ & 4865 & $1.8 \pm 2.2$ & $4.2 \pm 0.93$ & $3.8 \pm 0.75$ & $6.08 \pm 1.45$ \\
\hline IV & 420 & $522.1 \pm 54.25$ & 600 & 2100 & $4371.6 \pm 1141.7$ & 6700 & $1.7 \pm 1.67$ & $4.6 \pm 0.64$ & $2.5 \pm 0.50$ & $7.58 \pm 2.07$ \\
\hline
\end{tabular}


Table 3. - Diameter of size groups of oocytes from the ovary.

\begin{tabular}{cccc}
\hline Size group & Range & $\begin{array}{c}\text { Diameter }(\mathrm{mm}) \\
\text { Mean }\end{array}$ & SD \\
\hline I & $0.05-0.09$ & 0.07 & 0.045 \\
II & $0.09-0.28$ & 0.18 & 0.072 \\
III & $0.27-0.45$ & 0.36 & 0.051 \\
IV & $0.45-0.9$ & 0.62 & 0.081 \\
V & $0.8-0.98$ & 0.92 & 0.084 \\
VI & $0.9-1.1$ & 0.99 & 0.028 \\
\hline
\end{tabular}

preceding size group. Group III corresponded to the intercalary period of oocyte development. Oocytes were leaf-like, of dark colour, with numerous shallow, longitudinal grooves together with follicle cells that protruded into the grooves. The nucleus was not visible in this group. Group IV corresponded to the first and second phases of trophoplasmatic growth. Oocytes were covered with reticulate grooves, and were dark in colour. Group V corresponded to the third phase of trophoplasmatic growth. Oocytes were rounded and yellow and the reticulate grooves had almost disappeared. Group VI corresponded to the fourth phase of the trophoplasmatic growth. Oocytes had a smooth surface and were oval. Data on minimum and maximum size of oocytes are given in Table 3 . The percentage of oocytes belonging to different size groups changed as the reproductive system developed (Fig. 6). In immature females, oocytes of size group I were prevalent (76\%), with the remainder belonging to size groups II and III. Ripe oocytes were absent in maturing females. Mature and spawning state females always had group I oocytes, but with different percentages (Fig. 6). The relative number of ripe oocytes (group VI) was always low $(<1 \%)$ in mature and spawning state females, because they are immediately transferred into the oviducts after extrusion into the coelom. Individual PF varied considerably, ranging from 7 million oocytes in immature females to 2.4-7.0 million oocytes in maturing and mature females (Table 4).

\section{DISCUSSION}

\section{Structure of the reproductive organs}

The results of this study indicate that $O$. bartramii is an intermittent spawner that exhibits somatic growth between spawning events, as previously reported for $S$. oualaniensis (Harman et al. 1989), T. rhombus (Nigmatullin et al. 1995), Photololigo sp. (Moltschaniwskyj
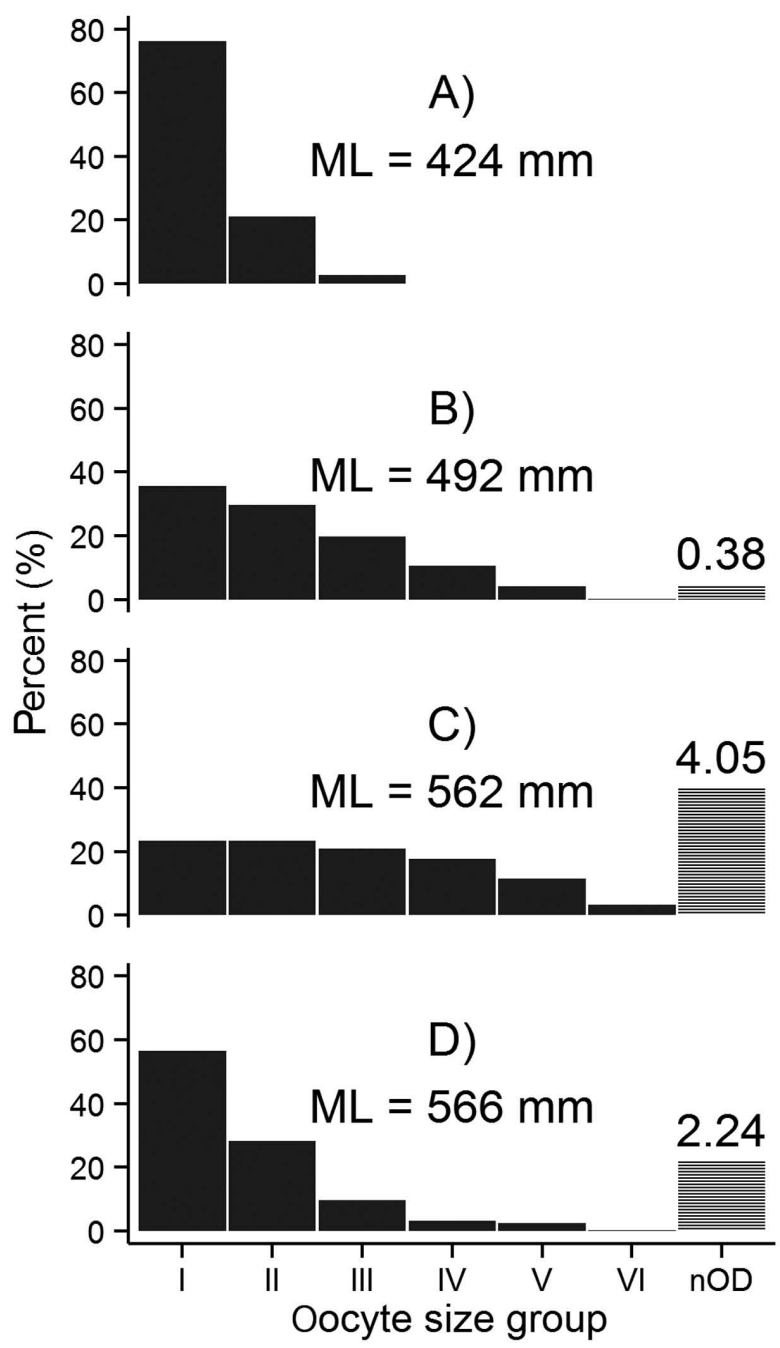

Fig. 6. - Frequency distribution of the different size groups of oocytes within the ovary of (a) immature, (b) maturing, (c) mature, and (d) spawning state (after the first spawning event) females of $\mathrm{Om}$ mastrephes bartramii. ML, mantle length; nOD, number of oocytes in oviducts (in millions).

1995), and other higher ommastrephids (Reznik and Bessmertnaya 1993, Nigmatullin and Laptikhovsky 1994, Zuyev et al. 2002, Laptikhovsky and Nigmatullin 2005, Nigmatullin 2011). The primary evidence supporting this suggestion is the lack of a strong correlation between body size and the number of mature oocytes in mature females, coupled with proof of the

Table 4. - Means of potential fecundity (PF, in millions), oviductal load (OL, in thousands), Ovary index (OSI, in \%), and oviduct index (ODSI, in \%) of $O$. bartramii collected in 2013 around the Hawaii region.

\begin{tabular}{|c|c|c|c|c|c|c|c|c|}
\hline Stage of maturity & $\mathrm{ML}(\mathrm{mm})$ & Weight $(\mathrm{g})$ & Ovary $(\mathrm{g})$ & Oviducts (g) & $\mathrm{PF}$ & $\mathrm{OL}$ & OSI & ODSI \\
\hline VI & 520 & 4144 & 176.5 & 69.5 & 3.44 & 114 & 4.26 & 1.68 \\
\hline VI & 552 & 4620 & 145 & 29.5 & 3.21 & 60 & 3.14 & 0.64 \\
\hline VI & 566 & 5290 & 204 & 233 & 4.52 & 224 & 3.86 & 4.40 \\
\hline V & 552 & 5034 & 234 & 411 & 7.05 & & 4.65 & 8.16 \\
\hline V & 559 & 5480 & 201 & 405.5 & 6.56 & & 3.67 & 7.40 \\
\hline V & 562 & 5196 & 260 & 470 & 7.22 & & 5.00 & 9.05 \\
\hline IV & 474 & 3564 & 154 & 113 & 3.56 & & 4.32 & 3.17 \\
\hline IV & 492 & 3908 & 141 & 40 & 2.39 & & 3.61 & 1.02 \\
\hline IV & 550 & 5162 & 272 & 156.5 & 5.53 & & 5.27 & 3.03 \\
\hline IV & 510 & 4640 & 200 & 140 & 4.65 & & 4.31 & 3.02 \\
\hline III & 424 & 2112 & 23 & & 7.1 & & 1.09 & \\
\hline
\end{tabular}




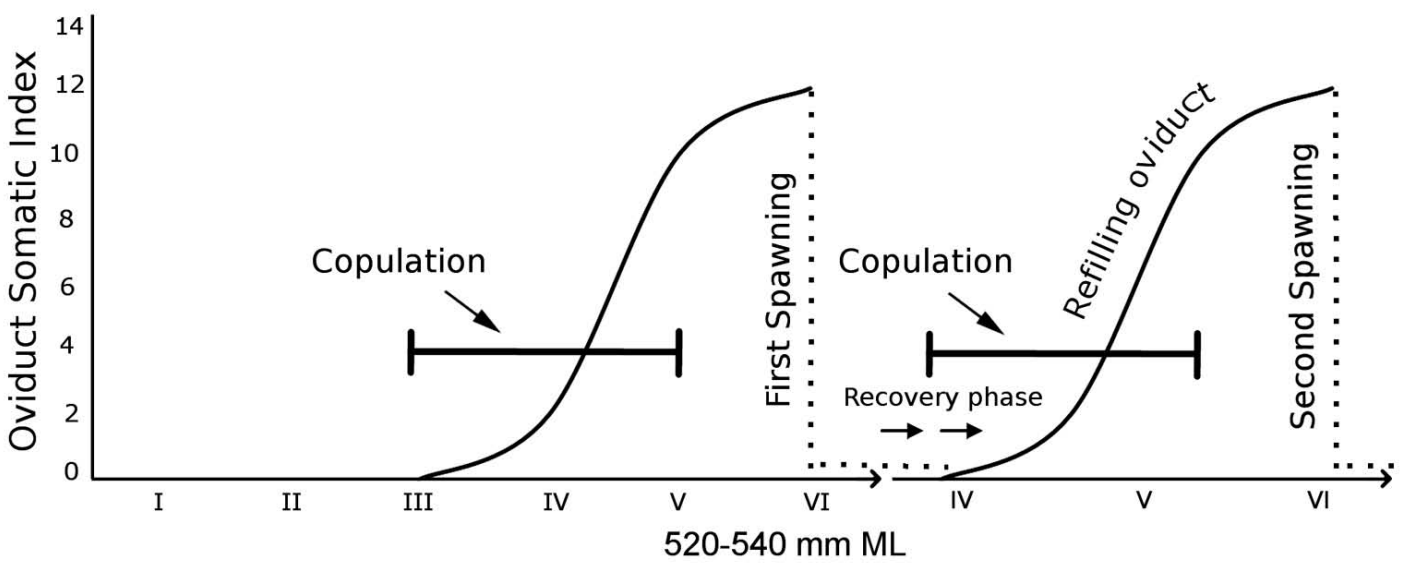

Maturity stages of female neon flying squid

Fig. 7. - Schematic of the spawning events of Ommastrephes bartramii. We assumed that the first spawning event occurs at $~ 520-540$ mm mantle length (ML). Subsequently, the female feeds, undergoes somatic growth, and refills the oviduct before the second spawning event commences.

occurrence of multiple filling and evacuation events in the oviduct. Ova are stored in the oviducts; hence, the fullness of the oviducts may be used as an indicator of repeated spawning. However, the fullness of the oviducts was not statistically correlated with body size in our study. Single spawners should show a gradual increase in oviduct fullness as size increases (Young et al. 1997), but this trend was not detected in the present data. Variability in oviduct fullness presents convincing evidence of batch spawning in females that grow substantially after reaching sexual maturity and continue to produce mature oocytes throughout this growth period.

$O$. bartramii females reach sexual maturity at $\sim 300 \mathrm{~mm}$ ML (Yatsu et al. 1998, Brunetti et al. 2006, Li et al. 2011), after which spawning occurs under favourable conditions. Because we did not find any sexually immature females with ML $>400 \mathrm{~mm}$, substantial growth must occur in females after attaining maturity (Yatsu et al. 1998, Li et al. 2011). A positive correlation is expected between ML and oviduct fullness (ODSI) for single spawning squids (e.g., $T$. pacificus, Ikeda et al. 1993), because the oocytes are produced and then develop in the ovaries before being transferred to the oviducts at stage VI for storage until spawning (Moltschaniwskyj 1995). However, the lack of correlation between ML and ODSI obtained in this study indicates that oocytes are present in the oviduct throughout stages IV, V, and VI. The OSI value showed the presence of oocytes in the ovaries of females with mature ML ranges (400-600 mm). This finding indicates that all stages of oocytes may be simultaneously present in the ovary. The somatic indices of 11 females at three maturity stages (latematuring, mature, and spawning state) collected from a single station (year 1992) are presented in Figure 4. For these females, the OSI value remained within a narrow range (2.5-4.0). Mature squid had high oviduct content but minimal stomach content (stomach content index [SCI], 0 to 0.2 ). In contrast, spawning state squid had smaller oviduct content but substantial stomach content (SCI, 1 to 4). Spawning state squid also had high $(6.58 \pm 2.05)$ HSI values showing the active digestive system. Thus, female $O$. bartramii seem to grow after reaching maturity, and continue to produce eggs throughout this period. Therefore, oocytes are expected to accumulate in the oviducts, unless spawning occurs (Moltschaniwskyj 1995). However, in the present study, oviduct fullness and ovary fullness (OSI) were generally unrelated to body size. This result is indicative of batch spawning. The presence of oocytes of all maturity stages indicates that oocytes are produced continuously and not in a single batch. After stomach content analysis, females appeared to forage irrespective of ML and maturity stage (Figs 3 and 4). These results indicate that the neon flying squid develops ova continuously, and not in a single batch (Nigmatullin and Laptikhovsky 1994, Nigmatullin et al. 1995). This finding is in contrast to the single spawning mode where all oocytes mature simultaneously (O’Dor 1983, Moltschaniwskyj 1995, Nixon 1983, Sakurai et al. 2000).

The nidamental glands of females produce the outside layer of egg masses during spawning (Bower and Sakurai 1996). Nidamental glands become enlarged and functional at sexual maturity. A single spawning female should show a gradual increase in nidamental gland size with increasing ML. In the current study, variation in nidamental gland weight and the fullness of oviducts indicated that the nidamental gland cycle is repeated through stages IV to V. This phenomenon occurs when the oviducts are filled and emptied in a squid exhibiting repeated spawning.

The skewed distribution of females might be an artifact of the capture techniques used. Mature females occupy deeper waters, making them less vulnerable to jigging (Young et al 1997) or trawling. Also, females are larger, so they find it easier easy to get off the hook when caught by jigger and they are faster at avoiding trawls. Therefore, large-size classes $(>550 \mathrm{~mm} \mathrm{ML})$ may be under-represented in the present data. The size difference between the sexes in our dataset is consistent with that reported in previous studies (Ichii et al. 2009, Yatsu et al. 1998). 


\section{Spawning pattern}

The mean size of a neon flying squid at maturity is $\sim 300-330 \mathrm{~mm}$ ML for males and $370-570 \mathrm{~mm}$ for females (Yatsu et al. 1998). Furthermore, females tend to be larger than males of the same age (Ichii et al. 2009). Yatsu et al. (1998) reported a peak in oviduct fullness for $O$. bartramii: $\sim 540 \mathrm{~mm}$ ML. This finding may indicate the size at which neon flying squid first spawn. Young et al (1997) also reported asynchronous ovulation in $O$. bartramii based on the size-frequency distribution of oocytes in the ovaries of 12 squids. From the results of these previous studies and our own findings, we hypothesize that the first spawning event in the neon flying squid occurs at $~ 520-540 \mathrm{~mm}$ ML (Fig. 7). Subsequently, the female feeds, undergoes somatic growth, and refills the oviduct. The second spawning event commences after the female has again passed through maturity stages IV and V (Fig. 7). Since our sample size was small, for calculating exact somatic growth between spawning events future studies are required. Multiple spawning has also been reported for related ommastrephids, including $S$. oualaniensis (Harman et al. 1989), S. pteropus (Laptikhovsky and Nigmatullin 2005), and Ornithoteuthis antillarum (Arkhipkin et al. 1998). Ichii et al. (2009) suggested that the extended spawning season of the neon flying squid might represent a risk-spreading strategy to reduce the chance of population collapse. The extended spawning season is achieved by dispersing the population through numerous seasonal cohorts and, possibly, through the occurrence of multiple spawning events. The lack of correlation between the body size and the accessory gland somatic index in males indicates that males continuously produce spermatophores. In the current study, these mature males were scattered throughout the distribution range of healthy spawning state females. Thus, it is possible that mating occurs between spawning events.

Based on our findings, we suggest that the spawning pattern of $O$. bartramii is similar to the pattern proposed for T. rhombus (Nigmatullin et al. 1995), D. gigas (Nigmatullin and Markaida, 2009), and both Sthenoteuthis species (Nigmatullin and Laptikhovsky 1994, Zuyev et al. 2002, Laptikhovsky and Nigmatullin 2005). We suggest the following life-history model for female $O$. bartramii. Specifically, the maximum number of oocytes forms by the end of stage II of maturity in immature individuals. At subsequent developmental stages, the total number of oocytes remains constant, but they start to develop asynchronously. As soon as the oocytes ripen, they are released from the follicles into the sexual coelom and are transferred to the oviducts, where they accumulate. At the same time, the nidamental and oviduct glands develop. When the oviducts are full of ripe eggs, a spawning event takes place, as long as the SST range is favorable $\left(21\right.$ to $\left.25^{\circ} \mathrm{C}\right)$.

\section{Spawning strategies}

Because of the high levels of PF, the presence of primary and secondary oocytes in the ovary of mature females indicates that $O$. bartramii invests in intermittent spawning, as described for T. rhombus (Nigmatullin et al. 1995), D. gigas (Nigmatullin and Markaida, 2009) and both Sthenoteuthis (Nigmatullin and Laptikhovsky, 1994, Zuyev et al. 2002, Laptikhovsky and Nigmatullin 2005). In other words, feeding occurs between spawning events (i.e. during the interval between each successive filling and evacuation event in the oviducts) at the spawning ground, fueling both somatic growth and new oocyte development. In a lifetime they might release just two or three large egg masses, and possibly spawning rates vary individually. Future studies should focus on determining the duration of maturity, the rate at which the oviducts fill between spawning events, and the length of intervals between spawning events. The spawning/nursery ground for the winter-spring cohort (subtropical domain) is an oligotrophic region where the flux of nutrients into the euphotic zone is probably the lowest of any oceanic environment (Cullen 1982, Eppley and Peterson 1979). Batch spawning may represent an adaptation to highly unstable environments, where a high rate of paralarval survival depends on favorable, but fortuitous and temporary, oceanographic conditions (Rocha et al. 2001). We subscribe to the concept proposed by Harman et al. (1989), whereby batch spawning might be a common strategy among tropical and subtropical squids.

\section{ACKNOWLEDGEMENTS}

We are grateful to the crew of R/V Hokusei Maru and R/V Kaiyo Maru and all cruise participants. The manuscript was greatly improved thanks to comments by John Bower and Puneeta Pandey of Hokkaido University, Japan. The study was funded by Hokkaido University and Fisheries Research Agency, Japan. We would like to thank Chingis Nigmatullin and two anonymous reviewers for their very useful comments and suggestions which help us improve the quality of our paper.

\section{REFERENCES}

Arkhipkin A.I., Laptikhovsky V.V., Nigmatullin Ch.M., et al. 1998. Growth, reproduction and feeding of the tropical squid Ornithoteuthis antillarum (Cephalopoda: Ommastrephidae) from the central - east Atlantic. Sci. Mar. 62: 273-288. http://dx.doi.org/10.3989/scimar.1998.62n3273

Bigelow K., Landgraph K. 1993. Hatch dates and growth of Ommastrephes bartramii paralarvae from Hawaiian waters as determined from statolith analysis. In: Okutani T., O'Dor R.K., Kubodera T. (eds), Recent Advances in Cephalopod Fisheries Biology. Tokai University Press, Tokyo, pp. 15-24.

Bower J.R., Ichii T. 2005. The red flying squid (Ommastrephes bartramii): A review of recent research and the fishery in Japan. Fish. Res. 76: 39-55. http://dx.doi.org/10.1016/j.fishres.2005.05.009

Bower J.R., Sakurai Y. 1996. Laboratory observations on Todarodes pacificus (Cephalopoda: Ommastrephidae) egg masses. Am. Malacol. Bull. 13: 65-71.

Boyle P. 1983. Cephalopod Life Cycles: Species Accounts. Academic Press, London.

Boyle P., Rodhouse P. 2005. Cephalopods: Ecology and Fisheries, Vol. 1. Blackwell Science Ltd., Oxford. http://dx.doi.org/10.1002/9780470995310

Brunetti N., Ivanovic M., Aubone A., et al. 2006. Reproductive biology of red squid (Ommastrephes bartramii) in the Southwest Atlantic. Revista de Investigación y Desarrollo Pesquero 18: 5-19. 
Calow P. 1987. Fact and theory - an overview. In: Boyle, P. (ed.), Cephalopod Life Cycles, Vol. 2. Comparative reviews. Academic Press, London, pp. 351-365.

Chen C.S., Chiu T.S. 2003. Variations of life history parameters in two geographical groups of the neon flying squid, Ommastrephes bartramii, from the North Pacific. Fish. Res. 63: 349-366. http://dx.doi.org/10.1016/S0165-7836(03)00101-2

Cullen J. 1982. The deep chlorophyll maximum: comparing vertical profiles of chlorophyll $a$. Can. J. Fish. Aquat. Sci. 39: 791-803 http://dx.doi.org/10.1139/f82-108

Durward R.D., Amaratunga T., O’Dor R.K. 1979. Maturation index and fecundity for female squid Illex illecebrosus (Leseue, 1821). ICNAF Res. Bull. 14: 67-72.

Eppley R., Peterson E. 1979. Particulate organic matter flux and planktonic new production in the deep ocean. Nature 282: 677-680. http://dx.doi.org/10.1038/282677a0

González Á.F., Guerra Á., 1996. Reproductive biology of the shortfinned squid Illex coindetii (Cephalopoda, Ommastrephidae) of the northeastern Atlantic. Sarsia 81: 107-118.

Harman R.F., Young R.E., Reid S.B., et al. 1989. Evidence for multiple spawning in the tropical oceanic squid Stenoteuthis oualaniensis (Teuthoidea: Ommastrephidae). Mar. Biol. 101: 513-519. http://dx.doi.org/10.1007/BF00541653

Ichii T., Mahapatra K., Sakai M., et al. 2009. Life history of the neon flying squid: effect of the oceanographic regime in the North Pacific Ocean. Mar. Ecol. Prog. Ser. 378: 1-11. http://dx.doi.org/10.3354/meps07873

Ikeda Y., Sakurai Y., Shimazaki K. 1993. Maturation process of the Japanese common squid Todarodes pacificus in captivity. In Okutani T., O’Dor R.K., Kubodera T. (eds), Recent Advances in Cephalopod Fisheries Biology. Tokai University Press, Tokyo, pp. 179-187.

Jereb P., Roper C.F.E. 2010. Myopsid and Oegopsid Squids, in Cephalopods of the World: An Annotated and Illustrated Catalogue of Cephalopods Species Known to Date. FAO Species Catalogue for Fisheries Purposes No 4 Vol 2.

Kidokoro H., Sakurai Y. 2008. Effect of water temperature on gonadal development and emaciation of Japanese common squid Todarodes pacificus. Fish. Sci. 74: 553-561. http://dx.doi.org/10.1111/j.1444-2906.2008.01558.x

Li S.L., Liu B.L., Chen X.J., et al. 2011. Reproductive biology of neon flying squid (Ommastrephes bartramii) in Northwest Pacific ocean. Oceanol. Limnol. Sinica 42: 179-185.

Laptikhovsky V. 2011. Ecology of Cephalopod reproduction. LAP Lambert Academic Publishing GmBH \& Co. Saarbrüchen, Germany. 233 pp. (In Russian).

Laptikhovsky V.V., Murzoy S.A. 1990. Epipelagic egg mass of the squid Sthenoteuthis pteropus collected in the tropical eastern Atlantic. Biologya Morya 3: 62-63.

Laptikhovsky V.V., Nigmatullin Ch.M. 1992. Caracteristicas reproductivas de machos y hembras de calamar (Illex argentinus). Frente Maritimo 12: 23-37.

Laptikhovsky V.V., Nigmatullin Ch.M. 1993. Egg size, fecundity, and spawning in females of the genus Illex (Cephalopoda, Ommastrephidae). ICES J. Mar. Sci. 50: 393-403. http://dx.doi.org/10.1006/jmsc.1993.1044

Laptikhovsky V.V., Nigmatullin Ch.M. 1999. Egg size and fecundity in females of the subfamilies Todaropsinae and Todarodinae (Cephalopoda: Ommastrephidae). J. Mar. Biol. Assoc. UK. 79: 569-570. http://dx.doi.org/10.1017/S002531549800071X

Laptikhovsky V.V., Nigmatullin Ch.M. 2005. Female reproductive biology of the orange-back squid, Sthenoteuthis pteropus (Steenstup) (Ommastrephidae: Oegopsidae) in the eastern tropical Atlantic. Sci. Mar. 69: 383-390.

Laptikhovsky V., Collins M.A., Arkhipkin A. 2013. First case of possible iteroparity among coleoid cephalopods: the giant warty squid Kondakovia longimana. J. Molluscan Stud. 79: 270-272. http://dx.doi.org/10.1093/mollus/eyt014

Moltschaniwskyj N.A. 1995. Multiple spawning in the tropical squid Photololigo sp.: what is the cost in somatic growth? Mar. Biol. 124: 127-135. http://dx.doi.org/10.1007/BF00349154

Murata M., Hayase S. 1993. Life history and biological information on flying squid (Ommastrephes bartramii) in the North Pacific Ocean. Int. North Pac. Fish. Comm. Bull. 53: 147-182.

Murata M., Nakamura Y. 1998. Seasonal migration and diel migration of the neon flying squid, (Ommastrephes bartramii), in the
North Pacific. In: Okutani, T. (ed.), International Symposium on Large Pelagic Squids. Japan Marine Fishery Resources Research Center, Tokyo, pp. 1330.

Nesis K. 1996. Mating, spawning, and death in oceanic cephalopods: a review. Ruthenica 6: 23-64.

Nigmatullin Ch.M. 1989. Las especies de calamar mas abundates del Atlantico Sudoeste y sinopsis sobre la ecologia del calamar (Illex argentinus). Frente Maritimo 5: 71-81.

Nigmatullin Ch.M. 1997. Egg size, fecundity, vitelline oocyte resorption, and spawning in the Gonatid squid, Berryteuthis magister (Gonatidae). In: 63rd Annual Meeting American Malacological Union (21-27 June 1997, Santa Barbara, California). Abstracts. pp. 46

Nigmatullin Ch.M. 2002. Ovary development, potential and actual fecundity and oocyte resorption in coleoid cephalopods: a review. In: International Symposium "Coleoid cephalopods through time" (17-19 September 2002, Berlin). Berliner Palabiologische Abhandlungen. Bd. pp. 82-84.

Nigmatullin Ch.M. 2011. Two spawning patterns in ommastrephid squids and other cephalopods. 4th International symposium "Coleoid cephalopods through time" (6-9 September 2011, Stuttgart, Germany). Abstract volume. Stuttgart: Museum fur Naturkunde Stuttgart. pp. 48.

Nigmatullin C.M., Laptikhovsky V.V. 1994. Reproductive strategies in the squids of the family Ommastrephidae (preliminary report). Ruthenica 4: 79-82

Nigmatullin Ch.M., Laptikhovsky V.V. 1999. Reproductive biology in females of the subfamilies Todaropsinae and Todarodinae (Cephalopoda: Ommastrephidae). Ruthenica 9: 63-75.

Nigmatullin C.M., Markaida U. 2009. Oocyte development, fecundity and spawning strategy of large sized jumbo squid Dosidicus gigas. J. Mar. Biol. Assoc. UK. 89: 789-801. http://dx.doi.org/10.1017/S0025315408002853

Nigmatullin C.M., Arkhipkin A.I., Sabirov R.M. 1995. Age, growth and reproductive-biology of diamond-shaped squid Thysanoteuthis rhombus (Oegopsida, Thysanoteuthidae). Mar. Ecol. Prog. Ser. 124: 73-87 http://dx.doi.org/10.3354/meps 124073

Nigmatullin C.M., Laptikhovsky V.V., Sabirov R.M. 1996. Reproductive biology of commander squid. In: Jelizarov A.A. (ed.), Commercial aspects of biology of commander squid Berryteuthis magister and of fishes of slope communities in the westrn part of the Bering Sea. Moscow: VNIRO Publ. pp. 101-124 (In Russian).

Nigmatullin C.M., Sabirov R.M., Zalygalin V.P. 2003. Ontogenetic aspects of morphology, size structure and production of spermatophores in ommmastrephid squids: an overview. In: Warnke K., Keupp H., Boletzky S.v. (eds), Coleoid cephalopods through time. Berliner Palabiologische Abhandlungen. Bd. pp. 225-240.

Nixon M. 1983. Teuthowenia megalops. In: Boyle, P. (ed.), Cephalopod Life Cycles, Vol. 1. Academic Press, pp. 233-247

O’Dor R.K. 1983. Illex illecebrosus. In: Boyle P. (ed.), Cephalopod Life Cycles, Vol. 1. Academic Press, pp. 175-199

O'Dor R.K., Dawe E. 1998. Illex illecebrosus. In: Rodhouse P., Dawe E.G., O’Dor R.K. (eds), Squid Recruitment Dynamics FAO Fish. Tech. Pap. 376. FAO, Rome, pp. 77-104

Okutani T., Tung I.H. 1978. Review of biology of commercially important squids in Japanese and adjacent waters. Symplectoteuthis oualaniensis (Lesson). Veliger 21: 87-95.

R Core Development Team 2013. R: A language and environment for statistical computing. R Foundation for Statistical Computing, Vienna, Austria. http://www.r-project.org/

Rasero M., González Á.F., Guerra Á. 1995. Spawning pattern and fecundity of the Ommastrephid squid Todaropsis eblanae in northeastern Atlantic waters. ICES CM1995/K9 1-18.

Reznik Y.I., Bessmertnaya N.B. 1993. Ripening, fecundity and spawning of neon flying squid (Ommastrephes bartramii) in the North West Pacific ocean. Bull. Int. North Pac. Fish. Comm. 53: part II: 205

Rocha F., Guerra Á., González Á.F. 2001. A review of reproductive strategies in cephalopods. Biol. Rev. 76: 291-304. http://dx.doi.org/10.1017/S1464793101005681

Roden G. 1991. Subarctic-subtropical transition zone of the North Pacific: large-scale aspects and mesoscale structure. NOAA National Marine Fisheries Service Technical Report, pp. 105-138.

Rodhouse P. 1998. Physiological progenesis in cephalopod molluscs. Biol. Bull. 195: 17-20. http://dx.doi.org/10.2307/1542771

Roper C.F.E., Nigmatullin C., Jereb P. 2010. Family Ommastre- 
phidae, In: Jereb, P., Roper, C.F.E. (eds), Cephalopods of the World: An Annotated and Illustrated Catalogue of Cephalopod Species Known to Date. Volume 2: Myopsid Oegopsid Squids. FAO Species Catalogue for Fisheries Purposes No. 4. Vol. 2. Rome, pp. 269-347.

Sakurai Y., Kiyofuji H., Saitoh S., et al. 2000. Changes in inferred spawning sites of Todarodes pacificus (Cephalopoda: Ommastrephidae) due to changing environmental conditions. ICES J. Mar. Sci. 57: 24-30. http://dx.doi.org/10.1006/jmsc.2000.0667

Staaf D.J., Camarillo-Coop S., Haddock S.H.D., et al. 2008. Natural egg mass deposition by the Humboldt squid (Dosidicus gigas) in the Gulf of California and characteristics of hatchlings and paralarvae. J. Mar. Biol. Assoc. UK. 88: 759-770.

http://dx.doi.org/10.1017/S0025315408001422
Yatsu A., Tanaka H., Mori J. 1998. Population structure of the neon flying squid, Ommastrephes bartramii, in the North Pacific Ocean. In: Okutani, T. (ed.), International Symposium on Large Pelagic Squids. Japan Marine Fishery Resources Research Center: Tokyo, pp. 31-48

Young R.E., Hirota J., Parry M. 1997. Aspects of the ecology of the red squid Ommastrephes bartramii, a potential target for a major Hawaiian fishery. FY 1997 Progress Report. Pelagic Fisheries Research Program, JIMAR.

Zuyev G., Nigmatullin Ch., Chesalin M., et al. 2002. Main results of long-term worldwise studies on tropical nektonic oceanic squid genus Sthenoteuthis: An overview of the Soviet investigations. Bull. Mar. Sci. 71(2): 1019-1060. 